\title{
THE DEVELOPMENT OF MULTIPLE EPRESENTATIONS BASED STUDENT WORKSHEET TO IMPROVE LEARNING RESULTS OF GRADE V ELEMENTARY SCHOOL STUDENTS
}

\author{
Hidari Akramida ${ }^{1}$, I Wayan Distrik ${ }^{*}$ 区 (i), Irawan Suntoro ${ }^{3}$ \\ 1Elementary School Teacher Education Department, University of Lampung, Indonesia \\ 2 Physics Education Department, University of Lampung, Indonesia \\ ${ }^{3}$ Social science education Department, University of Lampung, Indonesia
}

DOI: https://doi.org/10.29121/granthaalayah.v8.i8.2020.873

Article Type: Research Article

Article Citation: Hidari Akramida, I Wayan Distrik, and Irawan Suntoro. (2020). THE DEVELOPMENT OF MULTIPLE EPRESENTATIONS

BASED STUDENT WORKSHEET TO IMPROVE LEARNING RESULTS OF GRADE V ELEMENTARY SCHOOL STUDENTS. International Journal of Research -GRANTHAALAYAH, 8(8), 42-48.

https://doi.org/10.29121/granthaa layah.v8.i8.2020.873

Received Date: 26 July 2020

Accepted Date: 19 August 2020

Keywords:

Student Worksheet

Multiple Representations

Learning Result

\section{ABSTRACT}

The objective of this research was to develop Multiple Representations based student worksheet to improve elementary school learners' learning results in Way Kanan district, Lampung province, Indonesia. This research used Research and Development (R \& D) method by following steps made by Borg \& Gall, which were simplified into three stages; preliminary study, planning and development, and field test. It used static group pretestposttest design. Population was grade $V$ elementary school learners in Way Kanan district, Lampung, Indonesia. Samples were two classrooms of grade $\mathrm{V}$ elementary school learners and taken by using purposive random sampling. Data were collected with papers, test pencils, observation sheets and questionnaires. Data were analyzed by using descriptive and inferential analyses by using paired t-test. The research results showed that: 1) multiple representation based student worksheet theoretically valid shown by content validity by average of 92.37 out of 100 maximum score and construct validity by average of 91.02 and they belonged to very valid category; 2) multiple representation based student worksheet was practical and effective to use by grade $V$ elementary school learners and this was shown by average of learners' learning result averages by 75.00 in experiment classroom and 60.00 in control classroom.

\section{INTRODUCTION}

Curriculum 2013 is to prepare Indonesian people to have life ability as an individual and citizen with faith, who are productive, creative, innovative, and affective, and be able to be contributive to society, nation, and state life, and world civilization. Learner's success in thematic learning is influenced by how the educator is able to develop student worksheets in classrooms. A student worksheet can be made interestingly to help educators in learning in classrooms. Student worksheet is one of learning sources able to develop by educators as facilitators in learning activities. A student worksheet contains of pages consisting of tasks the learners must do to master required competences [1]. According to [2], a student worksheet is a printed teaching material in forms of pages containing materials, summaries, instructions of how task are done the learners must do by referring to basic competences to obtain. Composed student worksheet can be designed and developed according to conditions of learning activities to face.

(C) 2020 The Author(s). This is an open access article distributed under the terms of the Creative Commons Attribution License, which permits unrestricted use, distribution, and reproduction in any medium, provided the original author and source are credited. 
A proper student worksheet is presented with multiple representations, and this will be easier to understand by learners with their different abilities. Some learners are easier to understand materials either verbally, visually, or symbolically. A multiple representation-based student worksheet is easier to understand by learners, so that educators only function as facilitators. Multiple representation student worksheets are effectively used in the learning process [3] can improve students' metacognition skills [4].

Learners taught with multiple representations-based learning not only they enhance their knowledge, but they also reach higher level of and comprehensive understanding compared to control group taught with conventional method. In a multiple representation learning activity, learners are given problems and then they are to solve the problems with some methods such as problem solving by providing further explanations, using figures or mathematics as a language to explain the problems.

Multiple representations method is very helpful for learners in understanding abstract concepts and in problem solving [5]. A single representation may be easy to understand by some learners, but other learners may find difficulties to understand [6]. A learning material by using multiple representations would provide options for all learners in problem solving. A representation is able to represent, describe, or symbolize something and/or an event. Multiple representations mean to re-represent the same concept with different formats; verbally, visually, graphically, or mathematically [7].

The multi representations method has three main functions; to obtain additional information to support existing cognition processes and to mutually supporting, to limit interpretations that may occur, and to motivate learners in building understanding [8]. A student worksheet designed with multiple representations can help elementary school learners in obtaining additional information and to complement their not-yet-clear and complete-knowledge. The use of multiple representations in learning can also improve learners' learning results [9], [10], metacognition and concept understanding abilities [11], [3]

The problems of this research were: 1) how did multiple representations based student worksheet improve valid elementary school learners' learning results?; 2) how did the practicality and effectiveness of multiple representations based student worksheet in improving elementary school learners' learning results?

\section{RESEARCH METHOD}

\subsection{RESEARCH DESIGN}

This was a Research and Development (R \& D) by following 10 steps made by [12], but this research only used 7 steps and then simplified into 3 stages. They were: Step 1 - preliminary study, Step 2 - planning and development, and Step 3 - field test. The preliminary study step analyzed needs, observed some elementary schools, distributed questionnaires, and studied references. Planning and development composed story-board, indicators and lesson plans, assessments, observation sheets, questionnaires, and the student worksheet. The filed test step tested the student worksheet to see its practicality and effectiveness. This research used static group pretest-posttest design.

\subsection{RESEARCH SAMPLE}

This research used purposive sampling to take samples. Samples were taken based on location and same learners' initial abilities. Samples consisted of two classrooms; the experiment class room taught with multiple representations-based student worksheet and control class room taught with a student worksheet from the school that was composed by a book publisher. Each of experiment and control class rooms consisted of 20 students.

\subsection{RESEARCH INSTRUMENT}

Scoring sheets using Likert scale was used to measure student worksheet product validity. Practicality instrument consisted of student worksheet implementation observation sheets and responses of learners to the worksheet during learning. Effectiveness was measured by using tests. Instruments were validated by experts before usage and they were stated to be valid. 


\subsection{DATA ANALYSIS}

The student worksheet validity analyses, both valid in its construct and content, were done by scoring given by experts. Practicality data consisted of the student worksheet implementation that was analyzed by estimating average score of each learning aspect with Likert scale and then converted into 100 scale. The student worksheet implementation was then determined by average scores obtained based observation results done by observers (Table 1). Learners' responses to the student worksheet use were analyzed by using percentage, where $50 \%$ of learners stating very happy and happy to use the student worksheet would indicate positive responses and vice versa.

Table 1: Student worksheet implementation level in learning

\begin{tabular}{|c|c|}
\hline Achievement level & Qualification \\
\hline $81-100 \%$ & Excellent \\
\hline $61-80 \%$ & Good \\
\hline $41-60 \%$ & Fair \\
\hline $21-40 \%$ & Poor \\
\hline $0-20 \%$ & Very poor \\
\hline
\end{tabular}

Test result data were analyzed by using t-test inferential statistical analysis and n-gain score average analysis to find out the student worksheet effectiveness level. N-gain interpretation criteria are presented in Table 2.

Table 2: N-gain interpretation criteria

\begin{tabular}{|c|c|}
\hline Gain score & Criteria Interpretation \\
\hline $\mathrm{g}>0.7$ & High \\
\hline $0.3<\mathrm{g} \leq 0.7$ & Moderate \\
\hline $\mathrm{g} \leq 0.3$ & Low \\
\hline
\end{tabular}

\section{RESUL AND DISCUSSION}

\subsection{RESEARCH RESULT}

\subsubsection{STUDENT WORKSHEET VALIDATION RESULT BY EXPERT}

The validity of student worksheet consists of content and construct validity. the results of the validation by three experts are shown in Table 3.

Table 3: Validity of multiple representations-based student worksheet

\begin{tabular}{|c|c|c|c|c|}
\hline Item & Expert 1 & Expert 2 & Expert 3 & Average \\
\hline Content validity & 91.46 & 95.45 & 90.20 & 92.37 \\
\hline Construct validity & 90.38 & 92.25 & 90.45 & 91.02 \\
\hline
\end{tabular}

\subsubsection{STUDENT WORKSHEET PRACTICALITY}

\subsubsection{STUDENT WORKSHEET IMPLEMENTATION IN LEARNING}

Student worksheet implementation, in the theme 7 of thematic learning - events in life, sub-theme 3 - events to fill independence, was measured based on 5 aspects; (1) apperception, (2) cooperation/asking questions, (3) answering ability, (4) media use, and (5) being motivated. They are presented in Table 4. 
Hidari Akramida, I Wayan Distrik, and Irawan Suntoro

Table 4: Student worksheet implementation in thematic learning

\begin{tabular}{|c|c|c|c|}
\hline \multirow[t]{2}{*}{ Subject matter } & \multirow[t]{2}{*}{ Observation aspect } & \multicolumn{2}{|c|}{ Achievement } \\
\hline & & Experiment group & Control group \\
\hline \multirow{6}{*}{ Events to fill independence } & Apperception & 85.00 & 81.38 \\
\hline & Cooperation/asking question & 87.17 & 80.50 \\
\hline & Answering ability & 82.25 & 81.25 \\
\hline & Media use & 85.00 & 80.00 \\
\hline & Motivating learner & 87.00 & 81.25 \\
\hline & Average & 85.28 & 80.88 \\
\hline
\end{tabular}

\subsubsection{LEARNERS'RESPONSES TO THE STUDENT WORKSHEET}

Learners' responses to the student worksheet consist of 8 questions related to attractiveness, easiness, and difficulty during learning by using the student worksheet. Learners' responses to the student worksheet are presented in Table 5.

Table 5: Learners' responses to the student worksheet

\begin{tabular}{|c|c|c|c|}
\hline \multirow[t]{2}{*}{ No } & \multirow[t]{2}{*}{ Statement } & \multirow[t]{2}{*}{ Response } & Response percentage (\%) \\
\hline & & & Experiment classroom \\
\hline \multirow[t]{4}{*}{1} & \multirow[t]{4}{*}{ Student's impression } & Very happy & 45.00 \\
\hline & & Happy & 50.28 \\
\hline & & Indifferent & 3.52 \\
\hline & & Not attractive & 1.20 \\
\hline \multirow[t]{4}{*}{2} & \multirow[t]{4}{*}{ Benefit } & Very helpful & 70.00 \\
\hline & & Helpful & 25.25 \\
\hline & & Indifferent & 2.70 \\
\hline & & Unhelpful & 2.05 \\
\hline \multirow[t]{4}{*}{3} & \multirow[t]{4}{*}{ student Worksheet presentation } & Very easy & 40.78 \\
\hline & & Easy & 50.19 \\
\hline & & Indifferent & 5.89 \\
\hline & & More difficult & 3.14 \\
\hline \multirow[t]{4}{*}{4} & \multirow[t]{4}{*}{ Material sequence } & From easy to difficult & 50.51 \\
\hline & & Sometimes easy and sometimes difficult & 40.00 \\
\hline & & Indifferent & 3.11 \\
\hline & & All are difficult & 6.38 \\
\hline \multirow[t]{4}{*}{5} & \multirow[t]{4}{*}{ Material explanation } & Easy to understand & 50.00 \\
\hline & & Easy enough to understand & 47.45 \\
\hline & & Indifferent & 2.55 \\
\hline & & Difficult to understand & 0 \\
\hline \multirow[t]{4}{*}{6} & \multirow[t]{4}{*}{ Understanding difficult material } & Very helpful & 68,80 \\
\hline & & Helpful & 30.00 \\
\hline & & Indifferent & 1.20 \\
\hline & & Unhelpful at all & 0 \\
\hline \multirow{2}{*}{\multicolumn{2}{|c|}{ Learner's average response }} & Positive & 94.71 \\
\hline & & Negative & 5.29 \\
\hline
\end{tabular}

\subsubsection{EFFECTIVENESS STUDENT WORKSHEET}

The summary of pretest, posttest, and n-gain results of learners' learning results are presented in Table 6. 
The Development of Multiple Epresentations Based Student Worksheet to Improve Learning Results of Grade V Elementary School Students

Table 6: Summary of pretest, posttest, and n-gain results of learners' learning results

\begin{tabular}{|c|c|c|c|}
\hline \multirow{2}{*}{ Classroom } & \multicolumn{3}{|c|}{ Events to fill independence } \\
\cline { 2 - 5 } & 01 & 02 & N-gain \\
\hline Experiment classroom & 46.25 & 75.00 & 0,53 \\
\hline Control classroom & 41.25 & 60.00 & 0.32 \\
\hline
\end{tabular}

Note: 01 (Pre-test); 02 (Post-test)

Table 6 shows that learners' learning results in thematic learning before teaching by using multi representations-based student worksheet is low; averagely 46.25 for experiment classroom and 41.25 for control classroom. After teaching by using multi representations-based student worksheet learners' learning result averages improve into 75.00 for experiment classroom and 60.00 for control classroom. The n-gains were 0.53 for experiment classroom (moderate category) and 0.32 for control classroom (low category).

\section{DISCUSSION}

The development of multiple representations-based student worksheet was stated to be valid by experts in terms of its construct and content. The multiple representations-based student worksheet for grade $V$ was designed according to revised curriculum 2013 prevailing in Indonesia. This student worksheet was also designed according to learning theories, learning objectives to achieve, teaching student behavior, and learning environment [13]. The lesson material composition in the student worksheet was to explain every concept had been identified with some methods (verbal, visual, and symbol), so that learners were easy to understand. Materials were presented structurally from the simplest to most complicated problems. The multiple representations-based student worksheet for grade V students of elementary school had 5 main elements as [14] suggested; having (1) learning steps, (2) social system, (3) reaction principle, (4) supporting system, and (5) instructional and nurturant effects. Based on three experts' assessments, this student worksheet was stated to be valid theoretically.

Student worksheet implementation in thematic learning of Theme 7 - sub theme 3; the events to fill independence, was measured based on 5 aspects; apperception, cooperation/asking question, answering ability, and media use. The experiment classroom showed achievements of all aspects by average of 85.28 and the control classroom showed achievements of all aspects by average of 80.88. Teachers were able to implement each of subject material excellently, so that the social system and reaction principle could be implemented excellently. The supporting system such as visual media use and other displaying instruments could be implemented properly by teachers. In addition, instructional effects such as predetermined learning objectives could be achieved properly, even though it was still in moderate category of n-gain. Learners' responses to the multi representations-based student worksheet consisted of 8 questions related to attractiveness, easiness, and difficulty during learning by implementing the student worksheet. The averages for all aspects in experiment classroom were $94.7 \%$ positive responses and $5.29 \%$ negative responses.

Learners' learning results in this research were obtained by pretests and posttests in experiment and control classrooms. The pretest score averages for experiment and control classrooms were 46.25 and 41.25 respectively. The posttest score averages for experiment and control classrooms after treatment were 75.00 and 60.00 respectively. The posttest score average of experiment classroom was higher compared to control classroom. $\mathrm{N}$-gain between pretest and posttest scores were 0.53 for experiment classroom (moderate category) and 0.32 for control classroom (low category). For example, students in the experiment classroom were able to explain some figures verbally. They were also able to describe cycle processes of liquid, solid, and gas substances. In addition, students were also able to represent some data in graphics.

Multiple representations-based student worksheet was able to help students in understanding more difficult problems by some students. This finding is in line with finding by [6] suggesting that the multiple representationsbased student worksheet is able to help students to solve physics problems. The finding by [15] also affirms that multiple representations-based student worksheet can help students to solve problems properly. Explaining a concept with some methods would help students with varying intelligence levels and learning styles. 


\section{CONCLUSION}

Based on the expert and empirical test results, the multiple representations based student worksheet in the vents in life material for grade $\mathrm{V}$ of elementary school students, the conclusions are as follows; 1) the student worksheet is valid and this is indicated by 92.37 average score for content validity and 91.02 average score for construct validity; 2 ) the student worksheet is practical and it is shown by implementation average score of 85.28 , meaning that this student worksheet is easy to implement by teachers and receiving positive responses from students; 3 ) effective to use in learning and it is indicated with learners' learning result average by 75.00 and n-gain by 0.53 in experiment classroom. Experiment classroom n-gain is higher compared to control classroom $(0.32)$ that belongs to low category.

\section{SOURCES OF FUNDING}

This research received no specific grant from any funding agency in the public, commercial, or not-for-profit sectors.

\section{CONFLICT OF INTEREST}

The author have declared that no competing interests exist.

\section{ACKNOWLEDGMENT}

None.

\section{REFERENCES}

[1] Fhadhila, F., Ertikanto, C., Rosidin, R. (2018) Pengembangan Lembar Kerja Peserta Didik pada Materi Suhu dan Kalor berdasarkan Keterampilan Proses Ilmiah. Jurnal Ilmiah Pendidikan Fisika Al-Biruni.

[2] Prastowo, Andi. 2011. Panduan Kreatif Membuat Worksheet Inovatif. Diva Press. Yogyakarta.

[3] Yanti, H., Distrik, I W, \& Rosidin, U. 2019. The Effectiveness of Students' Worksheets Based on MultiRepresentation in Improving Students' Metacognition Skills in Static Electricity. IOP Conf. Series: Journal of Physics: Conf. Series 1155 (2019) 012083. https:// doi:10.1088/1742-6596/1155/1/012083.

[4] Distrik, I W., Ertikanto, C. Suyatna, A., \& Suana, W. (2018). The Effect of Real Model in Enhancing Metacognition of Abstract Physics Topic. International Journal of Research - Granthaalayah, 6(6), 389- 395. https://doi.org/10.5281/zenodo.1310000

[5] Van Heuvelen, A., \& Zou, X. (2001). Multiple representations of work-energy

[6] Citra, C., Distrik, I W., \& Herlina. (2019). Representations Based Teaching Material to Improve Student's SelfEfficacy and Ability of Physics Problem Solving. Journal of Physics: Conf. Series 1467 (2020) 012029

[7] Waldrip, B., Prain, V., \&Carolan, J. (2006). Learning junior secondary science through multi-modal representations. Electronic Journal of Science Education, 11(1), 87-107.

[8] Ainsworth, S. (2008). The Educational Value of Multiple-Representations when Learning Complex Scientific Concepts. Visualization: Theory and Practice in Science Education, 1-15.

[9] Abdurrahman, Liliasari., A Rusli, \& B Waldrip. 2011. Implementasi Pembelajaran Berbasis Multirepresentasi untuk Peningkatan Penguasaan Konsep Fisika Kuantum. Cakrawala Pendidikan, jurnal ilmiah pendidikan. 30(1): 30-45.

[10] Hand, B., Gunel, M., \&Ulu, C. (2009). Sequencing embedded multimodal representations in a writing to learn approach to the teaching of electricity. Journal of Research in Science Teaching, 46(3), 225-247.

[11] Distrik, I. W. (2016). Model Pembelajaran "REAL" untuk Meningkatkan Kemampuan Metakognisi, Pemahaman Konsep, dan Kemampuan Pemecahan Masalah Listrik dan Magnet pada Mahasiswa Calon Guru Fisika. Disertasi, Program Pascasarjana. Surabaya: Program Studi Pendidikan Sains.

[12] Borg, W.R. \& Gall, M.D. (1983). Educational Research: An Introduction, Fifth Edition. New York: Longman. 
[13] Arends, R.I. (2007). Learning to Teach. McGraw Hill Companies. Inc. 1221 Avenue of the Americas, New York, NY 10020.

[14] Joyce, Bruce \& weil Marsha. (2003). Model of Teaching. Fifth Edition. Prentice-Hall of India, Private Limited New Delhi 110001.

[15] Nguyen, D. H., \& Rebello, N.S. (2011). Students' Difficulties with Multiple Representation in Introductory Mechanics. David Publishing, 8(5), 559 - 569 